\title{
Mapping the Prevalence and Sociodemographic Characteristics of Women Who Deliver Alone: Evidence From Demographic and Health Surveys From 80 Countries
}

\author{
Nosakhare Orobaton, ${ }^{a}$ Anne Austin, ${ }^{b}$ Bolaji Fapohunda, ${ }^{c}$ Dele Abegunde, ${ }^{c}$ Kizzy Omoc
}

An estimated 2.2 million women surveyed in low- and middle-income countries between 2005 and 2015 gave birth alone. This practice was concentrated in West and Central Africa and parts of East Africa. Women who delivered with no one present were very poor, uneducated, older, and of higher parity. Experience from northern Nigeria suggests the practice can be reduced markedly by mobilizing religious and civil society leaders to improve community awareness about the critical importance of having an attendant present.

\section{ABSTRACT}

Evidence has shown that quality skilled care during labor and delivery is essential to improve maternal and newborn health outcomes. Unfortunately, analyses of Demographic and Health Survey (DHS) data show that there are a substantial number of women around the world that not only do not have access to skilled care but also deliver alone with no one present (NOP). Among the 80 countries with data, we found the practice of delivering with NOP was concentrated in West and Central Africa and parts of East Africa. Across these countries, the prevalence of giving birth with NOP was higher among women who were poor, older, of higher parity, living in rural areas, and uneducated than among their counterparts. As women increased use of antenatal care services, the proportion giving birth with NOP declined. Using census data for each country from the US Census Bureau's International Database and data on prevalence of delivering with NOP from the DHS among countries with surveys from 2005 onwards $(n=59)$, we estimated the number of women who gave birth alone in each country, as well as each country's contribution to the total burden. Our analysis indicates that between 2005 and 2015, an estimated 2.2 million women, who had given birth in the 3 years preceding each country survey, delivered with NOP. Nigeria, alone, accounted for $44 \%$ (nearly 1 million) of these deliveries. As countries work on reducing inequalities in access to health care, wealth, education, and family planning, concurrent efforts to change community norms that condone and facilitate the practice of women giving birth alone must also be implemented. Programmatic experience from Sokoto State in northern Nigeria suggests that the practice can be reduced markedly through grassroots community advocacy and education, even in poor and low-resource areas. It is time for leaders to act now to eradicate the practice of giving birth alone-one of many important steps needed to ensure no mother or newborn dies of a preventable death.

\section{INTRODUCTION}

$\mathbf{T}$ he United Nations Sustainable Development Goals (SDGs), endorsed in September 2015, provide a framework for improving population health outcomes for billions of people globally. The SDGs cover many topics from poverty eradication to climate change and represent a global consensus on an agenda to reduce inequalities. ${ }^{1}$

a JSI Research \& Training Institute, Inc., United States Agency for International Development (USAID) I Targeted States High Impact Project (TSHIP), Washington, DC, USA.

b JSI Research \& Training Institute, Inc., USAID I TSHIP, Boston, MA, USA.

'JSI Research \& Training Institute, Inc., USAID I TSHIP, Abuja, Nigeria.

Correspondence to Anne Austin (amaustin123@gmail.com).
Of the 17 SDGs, the third one (ensure healthy lives and promote well-being for all at all ages) explicitly pertains to health outcomes. The first target under SDG 3 (target 3.1) calls for a reduction in the global maternal mortality ratio to fewer than 70 per 100,000 live births by 2030 . The second target under SDG 3 (target 3.2) aims to reduce newborn mortality to fewer than 12 deaths per 1,000 live births. ${ }^{2}$

Evidence has shown that quality, skilled care during labor and delivery is a required and key intervention to improve maternal and newborn health outcomes.,4 Unless every mother and newborn has access to such services, preventable maternal and newborn deaths are likely to continue and will jeopardize the attainment of 


\section{There is an additional sub- population of women, embedded among those who do not have access to quality skilled care, who deliver absolutely alone.}

An estimated 2.2 million deliveries with no one present occurred in 59 countries, with Nigeria accounting for $44 \%$.
SDG targets 3.1 and 3.2. Too many women and newborns, particularly in countries with weak health systems, social inequalities, and few available services, cannot access or afford high-quality maternity care. ${ }^{5}$

More alarmingly, there is an additional subpopulation of women and their newborns, embedded among those who do not have access to quality skilled care, who deliver absolutely alone with "no one present" (NOP). Delivery with NOP has recently become a focus of interest in Nigeria, although it has been neglected in most global policy and practice discussions. ${ }^{6-8}$ Published work on women giving birth with NOP in other countries and regions of the world is scant. We believe that this is an omission; women who give birth alone are denied the social support of companionship during birth and have no one to act on their behalf as a timely conduit to the health system in the event of maternal or newborn complications. Under such a scenario, this subset of women is likely to contribute disproportionately to the burden of maternal and neonatal mortality. This paper identifies differentials in the prevalence and socioeconomic characteristics of women who delivered with NOP among the 80 countries with available DHS data. This is an important first step in developing interventions to eradicate the practice, and ultimately in achieving SDG targets 3.1 and 3.2.

\section{DATA AND METHODS}

Since 1984, the Demographic and Health Surveys (DHS) have been conducted in at least 85 countries. $^{9}$ DHS data have documented the association between skilled assistance at delivery and lower rates of mortality and morbidity among mothers and their newborns. ${ }^{10,11}$ In addition to quantifying the prevalence of skilled birth attendance, the DHS also explicitly collects data on women who gave birth with NOP.

For our analysis, we used publicly available data from the DHS program's STATcompiler database to profile the distribution of delivery with NOP across countries, as well as to identify which subpopulations within countries were most likely to engage in this risky practice. ${ }^{12}$ Data on women giving birth alone were available for 80 countries. The STATcompiler database also enabled us to stratify all live births that occurred with NOP in the 3 years preceding the most recent country DHS survey on several indicators. The variables available were urban/rural residence, wealth quintile, mother's age, number of antenatal care (ANC) visits, birth order, and mother's level of education. Although most countries had full data on these stratification variables, some disaggregated data were missing for Botswana, Ecuador, El Salvador, Mexico, Sri Lanka, Sudan, Thailand, and Trinidad and Tobago.

We also sought to estimate each country's contribution to the total burden of women who gave birth alone among surveyed countries. In doing this, we used the mid-year population of women between the ages of $15-49$, as calculated by the US Census Bureau's International Database, during the same year as each DHS, adjusted for the general fertility rates (as presented in STATcompiler) for the 3 years preceding each survey year. For these analyses, we found census data for the same year as the DHS data for 77 countries. (Census data were missing for Ecuador, Sudan, and Thailand and were excluded from the analysis because they did not have recent DHS surveys conducted after 2004; see below. $)^{13}$

These numbers were used to calculate a rough estimate of the number of women who would have given birth alone, given the prevalence rates of delivery with NOP at the time of the most recent DHS survey after 2004. We excluded 18 countries in the final analyses (besides Ecuador, Sudan, and Thailand mentioned above) as they had no data available after 2004. These countries were Botswana, Brazil, Central African Republic, Chad, Eritrea, Guatemala, Mauritania, Mexico, Morocco, Nicaragua, Paraguay, South Africa, Sri Lanka, Trinidad and Tobago, Turkey, Turkmenistan, Uzbekistan, and Vietnam. This yielded a total of 59 countries with recent data that were used to assess the number of women giving birth alone.

Data from the DHS and the US Census Bureau are both open access and publicly available. Additionally, as standard protocol, each DHS survey received in-country ethical clearance. As both of these data sources are anonymized, we did not seek any additional ethical approval for this work.

\section{RESULTS}

\section{Estimated Magnitude of Delivery With NOP}

For the 59 countries with data since 2005, we estimated there were 2.2 million deliveries with NOP in the 3 years preceding the most recent country survey (Table 1). On a country-by-country basis, the number of women who gave birth alone in 7 countries (Nigeria, India, Niger, Tanzania, Ethiopia, Uganda, and Kenya) made up $78 \%$ of the total number of women who gave birth alone. Although the proportion of women who gave birth 
TABLE 1. Estimated Number of Women Who Gave Birth With No One Present (NOP) and Percent Contribution of Each Country to the Total Number of Births With NOP, Selected Countries With DHS Data Between 2005 and $2015^{a}$

\begin{tabular}{|c|c|c|c|c|c|}
\hline $\begin{array}{l}\text { Country \& } \\
\text { Survey Year }\end{array}$ & $\begin{array}{c}\text { Population of } \\
\text { Women Aged } \\
15-49\end{array}$ & $\begin{array}{c}\text { General Fertility } \\
\text { Rate/1,000 } \\
\text { Women Aged } \\
15-44^{6}\end{array}$ & $\begin{array}{l}\text { Percentage of } \\
\text { Live Births With } \\
\text { NOP }\end{array}$ & $\begin{array}{l}\text { Estimated Number } \\
\text { of Women Giving } \\
\text { Birth With NOP }\end{array}$ & $\begin{array}{l}\text { Estimated Percent } \\
\text { Contribution } \\
\text { to the Total Number of } \\
\text { Births With NOP Among } \\
\text { All Surveyed Countries }\end{array}$ \\
\hline Nigeria 2013 & $39,466,768$ & 0.190 & $13.00 \%$ & 974,829 & $44.22 \%$ \\
\hline India 2005 & $279,621,419$ & 0.101 & $0.50 \%$ & 141,209 & $6.41 \%$ \\
\hline Niger 2012 & $3,423,589$ & 0.269 & $14.50 \%$ & 133,537 & $6.06 \%$ \\
\hline Tanzania 2011 & $10,465,797$ & 0.188 & $6.70 \%$ & 131,827 & $5.98 \%$ \\
\hline Ethiopia 2011 & $20,405,177$ & 0.161 & $3.80 \%$ & 124,839 & $5.66 \%$ \\
\hline Uganda 2011 & $7,234,128$ & 0.217 & $6.80 \%$ & 106,747 & $4.84 \%$ \\
\hline Kenya 2008 & $9,361,636$ & 0.161 & $6.50 \%$ & 97,970 & $4.44 \%$ \\
\hline Angola 2006 & $3,385,034$ & 0.198 & $8.40 \%$ & 56,300 & $2.55 \%$ \\
\hline Mali 2012 & $3,524,985$ & 0.214 & $5.80 \%$ & 43,752 & $1.98 \%$ \\
\hline DRC 2013 & $18,043,728$ & 0.225 & $0.80 \%$ & 32,479 & $1.47 \%$ \\
\hline Guinea 2012 & $2,518,996$ & 0.176 & $7.10 \%$ & 31,477 & $1.43 \%$ \\
\hline Rwanda 2010 & $2,650,841$ & 0.151 & $7.30 \%$ & 29,220 & $1.33 \%$ \\
\hline Cameroon 2011 & $4,993,439$ & 0.180 & $3.10 \%$ & 27,863 & $1.26 \%$ \\
\hline Nepal 2011 & $7,986,822$ & 0.096 & $2.90 \%$ & 22,235 & $1.01 \%$ \\
\hline Côte d'Ivoire 2011 & $5,293,915$ & 0.174 & $2.40 \%$ & 22,107 & $1.00 \%$ \\
\hline Ghana 2008 & $5,654,518$ & 0.136 & $2.70 \%$ & 20,763 & $0.94 \%$ \\
\hline Zambia 2013 & $3,274,651$ & 0.184 & $3.10 \%$ & 18,679 & $0.85 \%$ \\
\hline Malawi 2010 & $3,388,791$ & 0.202 & $2.70 \%$ & 18,482 & $0.84 \%$ \\
\hline Yemen 2013 & $6,040,827$ & 0.206 & $1.40 \%$ & 17,422 & $0.79 \%$ \\
\hline Bangladesh 2011 & $43,392,926$ & 0.092 & $0.40 \%$ & 15,969 & $0.72 \%$ \\
\hline Burundi 2010 & $2,068,122$ & 0.203 & $3.60 \%$ & 15,114 & $0.69 \%$ \\
\hline Senegal 2014 & $3,435,961$ & 0.172 & $2.50 \%$ & 14,775 & $0.67 \%$ \\
\hline Pakistan 2012 & $48,212,804$ & 0.131 & $0.20 \%$ & 12,632 & $0.57 \%$ \\
\hline Mozambique 2011 & $5,453,352$ & 0.206 & $1.10 \%$ & 12,357 & $0.56 \%$ \\
\hline Zimbabwe 2010 & $2,894,645$ & 0.150 & $2.80 \%$ & 12,158 & $0.55 \%$ \\
\hline Indonesia 2012 & $65,894,656$ & 0.088 & $0.20 \%$ & 11,597 & $0.53 \%$ \\
\hline Burkina Faso 2010 & $3,688,866$ & 0.206 & $1.40 \%$ & 10,639 & $0.48 \%$ \\
\hline Togo 2013 & $1,755,425$ & 0.163 & $3.10 \%$ & 8,870 & $0.40 \%$ \\
\hline Madagascar 2008 & $4,668,384$ & 0.168 & $0.80 \%$ & 6,274 & $0.28 \%$ \\
\hline
\end{tabular}


Table 1 (continued).

\begin{tabular}{|c|c|c|c|c|c|}
\hline $\begin{array}{l}\text { Country \& } \\
\text { Survey Year }\end{array}$ & $\begin{array}{c}\text { Population of } \\
\text { Women Aged } \\
15-49\end{array}$ & $\begin{array}{c}\text { General Fertility } \\
\text { Rate/ } 1,000 \\
\text { Women Aged } \\
15-44^{6}\end{array}$ & $\begin{array}{l}\text { Percentage of } \\
\text { Live Births With } \\
\text { NOP }\end{array}$ & $\begin{array}{l}\text { Estimated Number } \\
\text { of Women Giving } \\
\text { Birth With NOP }\end{array}$ & $\begin{array}{l}\text { Estimated Percent } \\
\text { Contribution } \\
\text { to the Total Number of } \\
\text { Births With NOP Among } \\
\text { All Surveyed Countries }\end{array}$ \\
\hline Haiti 2012 & $2,576,070$ & 0.117 & $1.90 \%$ & 5,727 & $0.26 \%$ \\
\hline Benin 2011 & $2,144,241$ & 0.175 & $1.10 \%$ & 4,128 & $0.19 \%$ \\
\hline Egypt 2014 & $22,030,793$ & 0.127 & $0.10 \%$ & 2,798 & $0.13 \%$ \\
\hline Bolivia 2008 & $2,478,335$ & 0.121 & $0.90 \%$ & 2,699 & $0.12 \%$ \\
\hline Philippines 2013 & $24,814,911$ & 0.101 & $0.10 \%$ & 2,506 & $0.11 \%$ \\
\hline Peru 2012 & $8,124,085$ & 0.086 & $0.30 \%$ & 2,096 & $0.10 \%$ \\
\hline Swaziland 2006 & 320,632 & 0.137 & $4.40 \%$ & 1,933 & $0.09 \%$ \\
\hline Colombia 2010 & $12,024,552$ & 0.074 & $0.20 \%$ & 1,780 & $0.08 \%$ \\
\hline Honduras 2011 & $2,084,188$ & 0.107 & $0.60 \%$ & 1,338 & $0.06 \%$ \\
\hline Timor-Leste 2009 & 242,026 & 0.175 & $3.00 \%$ & 1,271 & $0.06 \%$ \\
\hline Congo 2011 & $1,084,812$ & 0.182 & $0.50 \%$ & 987 & $0.04 \%$ \\
\hline Gambia 2013 & 486,629 & 0.085 & $1.90 \%$ & 786 & $0.04 \%$ \\
\hline Namibia 2013 & 583,375 & 0.125 & $0.90 \%$ & 656 & $0.03 \%$ \\
\hline Lesotho 2009 & 523,654 & 0.119 & $1.00 \%$ & 623 & $0.03 \%$ \\
\hline Azerbaijan 2006 & $2,637,985$ & 0.066 & $0.30 \%$ & 522 & $0.02 \%$ \\
\hline Sierra Leone 2013 & $1,391,263$ & 0.169 & $0.20 \%$ & 470 & $0.02 \%$ \\
\hline Jordan 2012 & $1,722,911$ & 0.112 & $0.20 \%$ & 386 & $0.02 \%$ \\
\hline Liberia 2013 & 928,619 & 0.168 & $0.20 \%$ & 312 & $0.01 \%$ \\
\hline Tajikistan 2012 & $2,128,742$ & 0.134 & $0.10 \%$ & 285 & $0.01 \%$ \\
\hline $\begin{array}{l}\text { Dominican Rep. } \\
2013\end{array}$ & $2,629,898$ & 0.089 & $0.10 \%$ & 234 & $0.01 \%$ \\
\hline Comoros 2012 & 181,215 & 0.142 & $0.90 \%$ & 232 & $0.01 \%$ \\
\hline Gabon 2012 & 376,360 & 0.144 & $0.40 \%$ & 217 & $0.01 \%$ \\
\hline Kyrgyzstan 2013 & $1,487,207$ & 0.125 & $0.10 \%$ & 186 & $0.01 \%$ \\
\hline Moldova 2005 & $1,083,166$ & 0.055 & $0.20 \%$ & 119 & $0.01 \%$ \\
\hline Guyana 2009 & 185,875 & 0.094 & $0.60 \%$ & 105 & $<0.01 \%$ \\
\hline Albania 2008 & 798,442 & 0.046 & $0.10 \%$ & 37 & $<0.01 \%$ \\
\hline Armenia 2010 & 849,511 & 0.061 & $0.00 \%$ & 0 & $<0.01 \%$ \\
\hline Cambodia 2010 & $4,088,903$ & 0.105 & $0.00 \%$ & 0 & $<0.01 \%$ \\
\hline
\end{tabular}


Table 1 (continued).

\begin{tabular}{|c|c|c|c|c|c|}
\hline $\begin{array}{l}\text { Country \& } \\
\text { Survey Year }\end{array}$ & $\begin{array}{c}\text { Population of } \\
\text { Women Aged } \\
15-49\end{array}$ & $\begin{array}{c}\text { General Fertility } \\
\text { Rate/1,000 } \\
\text { Women Aged } \\
15-44^{6}\end{array}$ & $\begin{array}{l}\text { Percentage of } \\
\text { Live Births With } \\
\text { NOP }\end{array}$ & $\begin{array}{l}\text { Estimated Number } \\
\text { of Women Giving } \\
\text { Birth With NOP }\end{array}$ & $\begin{array}{l}\text { Estimated Percent } \\
\text { Contribution } \\
\text { to the Total Number of } \\
\text { Births With NOP Among } \\
\text { All Surveyed Countries }\end{array}$ \\
\hline $\begin{array}{l}\text { Sao Tome and } \\
\text { Principe } 2008\end{array}$ & 39,078 & 0.164 & $0.00 \%$ & 0 & $<0.01 \%$ \\
\hline Ukraine 2007 & $12,201,772$ & 0.039 & $0.00 \%$ & 0 & $<0.01 \%$ \\
\hline Total & & & & $2,204,554$ & \\
\hline
\end{tabular}

with NOP was highest in Niger (at $14.5 \%$ ), the sheer number of women giving birth alone in Nigeria, estimated at almost 1 million in 2013, conferred Nigeria with a problem of greater absolute magnitude. We estimated that Nigeria alone contributed $44 \%$ of the total estimated number of women giving birth alone. ${ }^{9}$ It is also noteworthy that although only $0.5 \%$ of women in India gave birth alone in 2005, due to its large population, India contributed $6 \%$ of the total number of women giving birth alone.

\section{Regional Variations}

In Latin America and the Caribbean, the prevalence of women who gave birth alone was less than $3 \%$ in each country with survey data, with the exception of El Salvador where it was estimated at 7.6\% in 1985 (Table 2). In South and Southeast Asia, Timor-Leste (3\% in 2009) and Nepal (2.9\% in 2011) had the highest prevalence of women who gave birth alone. Central Asia had a very low prevalence of delivery with NOP, with all countries reporting a prevalence of less than $0.5 \%$, as did most North African, East European, and West Asian countries. Yemen was the main outlier in West Asia, reported at $4.4 \%$ of women who gave birth alone in 1997. In general, the highest prevalence of delivery with NOP was found in sub-Saharan Africa, where in 10 of 41 countries with data the prevalence was $5 \%$ or higher. The highest levels were in Nigeria at 13\% and Niger at $14.5 \%$ (Table 2). A mapping of available data that included the 80 countries revealed that delivery with
NOP was concentrated in West and Central Africa and parts of East Africa (Figure 1).

\section{Sociodemographic Correlates}

Table 2 shows that delivery with NOP is over- Prevalence of whelmingly a rural phenomenon in all the countries delivering alone with available data. Additionally, we observed a clear was higher association between wealth and delivery with NOP, with the poorest bearing the brunt of the burden in all countries with data. Finally, we found a clear age gradient; the prevalence of delivery with NOP rose as mothers got older in all countries. Furthermore, in 8 sub-Saharan African countries (and El Salvador), the prevalence of delivery with NOP among women over the age of 35 years ranged from $10 \%$ to $20 \%$.

When delivery with NOP was disaggregated by residence, wealth, and maternal age, Nigeria emerged as an outlier in terms of the large magnitude of the difference between urban and rural populations that gave birth alone. Nigeria had the highest percentage of both urban $(6.4 \%)$ and rural women (17\%) who gave birth alone. Nigeria also had the largest disparity between wealth categories, wherein $26 \%$ of women in the poorest quintile gave birth alone in 2013 in contrast to $2 \%$ in the wealthiest quintile. Furthermore, although there was a discernible linear trend showing that as mothers aged, they were more likely to have given birth alone, in Nigeria, as well as in Niger, nearly $10 \%$ of mothers under the age of 20 also reported they gave birth alone. 
TABLE 2. Percentage of Women Whose Most Recent Birth ${ }^{a}$ Occurred With No One Present, Stratified by Residence, Wealth Quintile, and Maternal Age

\begin{tabular}{|c|c|c|c|c|c|c|c|c|c|c|c|}
\hline \multirow[b]{2}{*}{ Country \& Survey Year } & \multirow[b]{2}{*}{ Total } & \multicolumn{2}{|c|}{ Residence } & \multicolumn{5}{|c|}{ Household Wealth Index } & \multicolumn{3}{|c|}{ Maternal Age at Birth } \\
\hline & & Urban & Rural & Lowest & Second & Middle & Fourth & Highest & $<\mathbf{2 0}$ & $20-34$ & $\geq 35$ \\
\hline \multicolumn{12}{|l|}{ sub-Saharan Africa } \\
\hline Angola 2006-07 & 8.4 & 3.5 & 13.7 & 15.5 & 13.0 & 5.8 & 3.9 & 0.6 & 5.8 & 9.2 & 17.3 \\
\hline Benin 2011-12 & 1.1 & 0.9 & 1.3 & 2.6 & 1.3 & 1.0 & 0.5 & 0.2 & 0.7 & 1.2 & 1.3 \\
\hline Botswana 1988 & 1.4 & 0.2 & 1.7 & NA & NA & NA & NA & NA & 0.0 & 1.6 & 2.5 \\
\hline Burkina Faso 2010 & 1.4 & 0.5 & 1.5 & 1.8 & 2.0 & 1.2 & 1.2 & 0.3 & 0.3 & 1.4 & 1.8 \\
\hline Burundi 2010 & 3.6 & 1.6 & 3.8 & 5.4 & 3.7 & 3.0 & 4.6 & 1.3 & 0.5 & 3.0 & 7.4 \\
\hline Cameroon 2011 & 3.1 & 1.3 & 4.4 & 8.1 & 3.6 & 1.6 & 0.6 & 0.3 & 2.2 & 3.1 & 4.3 \\
\hline Central African Republic 1994-95 & 1.8 & 1.4 & 2.1 & 1.5 & 2.7 & 2.7 & 1.4 & 0.7 & 0.2 & 1.9 & 4.2 \\
\hline Chad 2004 & 4.0 & 2.9 & 4.3 & 3.6 & 6.6 & 4.0 & 2.7 & 3.0 & 2.1 & 4.5 & 5.2 \\
\hline Comoros & 0.9 & 0.8 & 0.9 & 2.2 & 0.8 & 0.2 & 0.5 & 0.2 & 0.0 & 1.0 & 1.2 \\
\hline Congo (Brazzaville) 2011-12 & 0.5 & 0.1 & 1.1 & 1.5 & 0.4 & 0.1 & 0.2 & 0.0 & 0.3 & 0.5 & 0.7 \\
\hline Congo Democratic Republic 2013-14 & 0.8 & 0.5 & 1.0 & 1.4 & 0.9 & 1.0 & 0.4 & 0.3 & 0.3 & 0.8 & 1.4 \\
\hline Côte d'Ivoire 2011-12 & 2.4 & 0.7 & 3.4 & 3.5 & 2.6 & 2.6 & 2.0 & 0.6 & 0.7 & 2.6 & 3.4 \\
\hline Eritrea 2002 & 0.3 & 0.2 & 0.3 & 0.2 & 0.3 & 0.4 & 0.3 & 0.0 & 0.5 & 0.1 & 0.5 \\
\hline Ethiopia 2011 & 3.8 & 1.6 & 4.2 & 3.4 & 4.8 & 3.8 & 3.9 & 2.9 & 2.8 & 3.6 & 6.0 \\
\hline Gabon 2012 & 0.4 & 0.3 & 0.8 & 0.9 & 0.2 & 0.3 & 0.0 & 0.5 & 0.2 & 0.5 & 0.3 \\
\hline Gambia 2013 & 1.9 & 1.9 & 1.9 & 1.9 & 2.1 & 2.8 & 1.7 & 0.9 & 0.4 & 2.0 & 2.7 \\
\hline Ghana 2008 & 2.7 & 1.1 & 3.8 & 4.8 & 3.7 & 1.7 & 1.6 & 0.5 & 1.1 & 2.3 & 5.7 \\
\hline Guinea 2012 & 7.1 & 1.9 & 9.0 & 11.5 & 6.5 & 9.1 & 5.8 & 0.5 & 3.8 & 6.2 & 15.8 \\
\hline Kenya 2008-09 & 6.5 & 1.8 & 7.6 & 8.2 & 8.4 & 7.4 & 5.8 & 2.1 & 2.4 & 5.8 & 16.4 \\
\hline Lesotho 2009 & 1.0 & 0.6 & 1.1 & 1.4 & 0.7 & 2.0 & 0.5 & 0.3 & 0.5 & 1.2 & 0.7 \\
\hline Liberia 2013 & 0.2 & 0.0 & 0.4 & 0.6 & 0.1 & 0.1 & 0.0 & 0.1 & 0.1 & 0.2 & 0.3 \\
\hline Madagascar 2008-09 & 0.8 & 0.2 & 0.8 & 1.7 & 0.6 & 0.4 & 0.5 & 0.1 & 0.2 & 0.7 & 2.0 \\
\hline Malawi 2010 & 2.7 & 2.2 & 2.8 & 3.9 & 3.1 & 2.4 & 2.4 & 1.5 & 0.5 & 2.5 & 6.7 \\
\hline Mali 2012-13 & 5.8 & 2.0 & 6.7 & 7.7 & 6.7 & 8.0 & 4.5 & 1.1 & 3.9 & 5.8 & 8.1 \\
\hline Mauritania 2000-01 & 6.9 & 1.6 & 10.9 & 7.4 & 10.4 & 10.0 & 4.8 & 1.1 & 6.6 & 6.6 & 8.4 \\
\hline Mozambique 2011 & 1.1 & 1.2 & 1.1 & 0.5 & 1.4 & 0.9 & 1.2 & 1.8 & 0.9 & 0.9 & 2.6 \\
\hline Namibia 2013 & 0.9 & 0.2 & 1.5 & 2.3 & 0.8 & 0.4 & 0.5 & 0.0 & 0.0 & 0.9 & 1.6 \\
\hline Niger 2012 & 14.5 & 3.6 & 16.2 & 16.4 & 17.7 & 18.1 & 12.6 & 7.3 & 8.8 & 15.0 & 19.1 \\
\hline Nigeria & 13.0 & 6.4 & 16.7 & 25.7 & 17.4 & 10.5 & 5.1 & 1.6 & 9.1 & 12.8 & 17.8 \\
\hline
\end{tabular}


Table 2 (continued).

\begin{tabular}{|c|c|c|c|c|c|c|c|c|c|c|c|}
\hline \multirow[b]{2}{*}{ Country \& Survey Year } & \multirow[b]{2}{*}{ Total } & \multicolumn{2}{|c|}{ Residence } & \multicolumn{5}{|c|}{ Household Wealth Index } & \multicolumn{3}{|c|}{ Maternal Age at Birth } \\
\hline & & Urban & Rural & Lowest & Second & Middle & Fourth & Highest & $<\mathbf{2 0}$ & $20-34$ & $\geq 35$ \\
\hline Rwanda 2013 & 7.3 & 5.2 & 7.6 & 9.8 & 8.9 & 7.7 & 5.5 & 3.1 & 2.0 & 6.3 & 13.7 \\
\hline Sao Tome and Principe 2008-09 & 0.0 & 0.0 & 0.0 & 0.0 & 0.0 & 0.0 & 0.0 & 0.0 & 0.0 & 0.0 & 0.0 \\
\hline Senegal 2012-13 & 5.1 & 1.5 & 7.0 & 11.3 & 6.7 & 2.9 & 2.1 & 0.2 & 2.4 & 4.7 & 8.7 \\
\hline Sierra Leone 2013 & 0.2 & 0.1 & 0.2 & 0.3 & 0.2 & 0.1 & 0.2 & 0.0 & 0.0 & 0.2 & 0.2 \\
\hline South Africa 1998 & 2.1 & 0.6 & 3.5 & 5.4 & 2.3 & 0.5 & 0.5 & 0.0 & 1.1 & 2.1 & 3.0 \\
\hline Sudan 1989-90 & 4.3 & 2.1 & 5.5 & NA & NA & NA & NA & NA & 7.5 & 3.7 & 4.5 \\
\hline Swaziland 2006-07 & 4.4 & 1.5 & 5.3 & 11.3 & 4.8 & 1.8 & 2.1 & 1.2 & 2.1 & 3.7 & 14.2 \\
\hline Tanzania 2010 & 3.5 & 1.1 & 4.1 & 4.3 & 4.5 & 3.9 & 3.2 & 0.0 & 1.3 & 3.4 & 5.5 \\
\hline Togo 2013-14 & 3.1 & 0.8 & 4.4 & 5.2 & 5.1 & 3.4 & 1.0 & 0.3 & 1.5 & 2.8 & 5.4 \\
\hline Uganda 2011 & 6.8 & 1.0 & 7.7 & 8.8 & 8.7 & 9.0 & 5.2 & 1.1 & 1.4 & 6.5 & 14.2 \\
\hline Zambia & 3.1 & 1.1 & 4.1 & 4.5 & 4.6 & 3.2 & 1.2 & 0.4 & 0.4 & 2.5 & 9.4 \\
\hline Zimbabwe 2013-14 & 2.8 & 1.4 & 3.4 & 5.1 & 3.1 & 3.0 & 1.2 & 1.3 & 1.2 & 2.5 & 8.3 \\
\hline \multicolumn{12}{|c|}{ North Africa/West Asia and Eastern Europe } \\
\hline Albania 2008-09 & 0.1 & 0.2 & 0.0 & 0.3 & 0.0 & 0.0 & 0.0 & 0.0 & 0.9 & 0.0 & 0.0 \\
\hline Armenia 2010 & 0.0 & 0.0 & 0.0 & 0.0 & 0.0 & 0.0 & 0.0 & 0.0 & 0.0 & 0.0 & 0.0 \\
\hline Azerbaijan 2006 & 0.3 & 0.5 & 0.1 & 0.0 & 0.3 & 1.2 & 0.0 & 0.0 & 0.0 & 0.4 & 0.0 \\
\hline Egypt 2014 & 0.1 & 0.0 & 0.1 & 0.1 & 0.3 & 0.0 & 0.0 & 0.0 & 0.2 & 0.1 & 0.2 \\
\hline Jordan 2012 & 0.2 & 0.2 & 0.1 & 0.2 & 0.0 & 0.0 & 0.7 & 0.0 & 0.0 & 0.2 & 0.2 \\
\hline Moldova 2005 & 0.2 & 0.2 & 0.2 & 0.4 & 0.6 & 0.0 & 0.0 & 0.0 & 0.0 & 0.2 & 0.0 \\
\hline Morocco 2003-04 & 1.1 & 0.4 & 1.8 & 2.5 & 1.4 & 0.4 & 0.3 & 0.3 & 0.0 & 0.7 & 3.2 \\
\hline Turkey 1998 & 0.7 & 0.3 & 1.4 & 2.1 & 0.7 & 0.0 & 0.4 & 0.0 & 0.0 & 0.6 & 3.3 \\
\hline Ukraine 2007 & 0.0 & 0.0 & 0.0 & 0.0 & 0.0 & 0.0 & 0.0 & 0.0 & 0.0 & 0.0 & 0.0 \\
\hline Yemen 1997 & 4.4 & 2.7 & 4.9 & 3.6 & 4.1 & 5.8 & 5.2 & 3.5 & 2.0 & 4.2 & 7.7 \\
\hline \multicolumn{12}{|l|}{ Central Asia } \\
\hline Kyrgyz Republic 2012 & 0.1 & 0.0 & 0.2 & 0.0 & 0.0 & 0.6 & 0.0 & 0.0 & 0.0 & 0.2 & 0.0 \\
\hline Tajikistan 2012 & 0.1 & 0.1 & 0.1 & 0.5 & 0.0 & 0.1 & 0.0 & 0.0 & 0.0 & 0.1 & 0.8 \\
\hline Turkmenistan 2000 & 0.2 & 0.2 & 0.1 & 0.3 & 0.0 & 0.0 & 0.0 & 0.6 & 0.0 & 0.2 & 0.0 \\
\hline Uzbekistan 1996 & 0.4 & 0.0 & 0.6 & 0.8 & 0.0 & 1.0 & 0.0 & 0.0 & 0.0 & 0.4 & 1.9 \\
\hline \multicolumn{12}{|l|}{ South and Southeast Asia } \\
\hline Bangladesh 2011 & 0.4 & 0.2 & 0.5 & 0.7 & 0.9 & 0.4 & 0.1 & 0.0 & 0.2 & 0.6 & 0.0 \\
\hline Cambodia 2010 & 0.0 & 0.0 & 0.0 & 0.0 & 0.0 & 0.0 & 0.1 & 0.0 & 0.0 & 0.0 & 0.0 \\
\hline
\end{tabular}


Table 2 (continued).

\begin{tabular}{|c|c|c|c|c|c|c|c|c|c|c|c|}
\hline \multirow[b]{2}{*}{ Country \& Survey Year } & \multirow[b]{2}{*}{ Total } & \multicolumn{2}{|c|}{ Residence } & \multicolumn{5}{|c|}{ Household Wealth Index } & \multicolumn{3}{|c|}{ Maternal Age at Birth } \\
\hline & & Urban & Rural & Lowest & Second & Middle & Fourth & Highest & $<20$ & $20-34$ & $\geq \mathbf{3 5}$ \\
\hline India 2005-06 & 0.5 & 0.3 & 0.6 & 1.1 & 0.5 & 0.4 & 0.1 & 0.1 & 0.2 & 0.5 & 1.4 \\
\hline Indonesia 2012 & 0.2 & 0.1 & 0.4 & 0.8 & 0.2 & 0.1 & 0.0 & 0.0 & 0.4 & 0.2 & 0.4 \\
\hline Nepal 2011 & 2.9 & 1.4 & 3.0 & 7.7 & 2.6 & 1.0 & 0.8 & 0.3 & 0.8 & 3.0 & 7.2 \\
\hline Pakistan 2012-13 & 0.2 & 0.0 & 0.2 & 0.1 & 0.5 & 0.2 & 0.0 & 0.0 & 0.0 & 0.2 & 0.2 \\
\hline Philippines 2013 & 0.1 & 0.0 & 0.2 & 0.4 & 0.0 & 0.0 & 0.0 & 0.0 & 0.0 & 0.1 & 0.1 \\
\hline Sri Lanka 1987 & 0.2 & 0.0 & 0.3 & NA & NA & NA & NA & NA & 0.0 & 0.3 & 0.0 \\
\hline Thailand 1987 & 1.0 & 0.2 & 1.1 & NA & NA & NA & NA & NA & 0.4 & 0.6 & 5.0 \\
\hline Timor-Leste 2009-10 & 3.0 & 1.6 & 3.4 & 4.5 & 3.5 & 3.7 & 2.4 & 0.6 & 1.8 & 2.2 & 5.6 \\
\hline Vietnam 2002 & 0.1 & 0.0 & 0.1 & 0.2 & 0.2 & 0.0 & 0.0 & 0.0 & 0.0 & 0.1 & 0.0 \\
\hline \multicolumn{12}{|c|}{ Latin America and the Caribbean } \\
\hline Bolivia 2008 & 0.9 & 0.4 & 1.5 & 2.0 & 0.9 & 0.7 & 0.0 & 0.1 & 0.6 & 0.9 & 1.5 \\
\hline Brazil 1996 & 0.6 & 0.4 & 1.0 & 1.0 & 0.9 & 0.3 & 0.0 & 0.0 & 0.2 & 0.6 & 0.8 \\
\hline Colombia 2010 & 0.2 & 0.1 & 0.4 & 0.6 & 0.2 & 0.0 & 0.0 & 0.0 & 0.0 & 0.3 & 0.2 \\
\hline Dominican Republic 2013 & 0.1 & 0.1 & 0.0 & 0.1 & 0.1 & 0.2 & 0.0 & 0.0 & 0.0 & 0.1 & 0.0 \\
\hline Ecuador 1987 & 2.2 & 0.6 & 3.8 & NA & NA & NA & NA & NA & 0.4 & 2.0 & 5.7 \\
\hline El Salvador 1985 & 7.6 & 3.0 & 11.3 & NA & NA & NA & NA & NA & 4.5 & 7.8 & 13.5 \\
\hline Guatemala 1998-99 & 1.2 & 0.0 & 2.0 & 3.6 & 1.3 & 0.3 & 0.0 & 0.0 & 1.0 & 1.0 & 2.7 \\
\hline Guyana 2009 & 0.6 & 0.3 & 0.7 & 0.8 & 0.0 & 1.3 & 0.6 & 0.0 & 0.0 & 0.6 & 1.8 \\
\hline Haiti 2012 & 1.9 & 1.4 & 2.1 & 2.3 & 2.0 & 1.5 & 1.4 & 2.3 & 0.8 & 1.5 & 4.2 \\
\hline Honduras 2011-12 & 0.6 & 0.3 & 1.0 & 1.5 & 0.8 & 0.5 & 0.0 & 0.0 & 0.2 & 0.7 & 1.0 \\
\hline Mexico 1987 & 2.6 & 0.8 & 5.6 & NA & NA & NA & NA & NA & 0.5 & 2.7 & 4.9 \\
\hline Nicaragua 2001 & 1.1 & 0.5 & 1.7 & 2.6 & 1.2 & 0.4 & 0.3 & 0.1 & 0.3 & 1.0 & 3.8 \\
\hline Paraguay 1990 & 0.5 & 0.2 & 0.8 & 0.4 & 1.5 & 0.0 & 0.6 & 0.0 & 0.0 & 0.6 & 0.5 \\
\hline Peru 2012 & 0.3 & 0.2 & 0.7 & 1.0 & 0.3 & 0.0 & 0.2 & 0.0 & 0.0 & 0.3 & 0.8 \\
\hline Trinidad and Tobago 1987 & 0.1 & 0.0 & 0.2 & NA & NA & NA & NA & NA & 0.0 & 0.1 & 0.0 \\
\hline
\end{tabular}

a Data were restricted to the most recent live birth in the 3 years preceding each survey.

As women increased use of ANC, the proportion of women giving birth alone declined.
Table 3 presents the distribution of women who gave birth with NOP by number of ANC visits, the birth order of the index child, and maternal education. Across all countries, we observed that as women increased use of ANC, the proportion of women that gave birth with NOP declined. This is most clearly evident in Rwanda, where $36 \%$ of the women who reported they had given birth with NOP had not accessed any ANC compared with $9 \%$ of women who had made 1-3 ANC visits and 4\% of women with 4 or more ANC visits (Table 3). Of equal importance are those factors that enabled women to seek ANC as well as those that removed barriers to accessing ANC. We found that in all countries, women with higher-order births were more likely 


\section{FIGURE 1. Prevalence of Women Giving Birth With No One Present Among the 80 Countries With Available DHS Data}

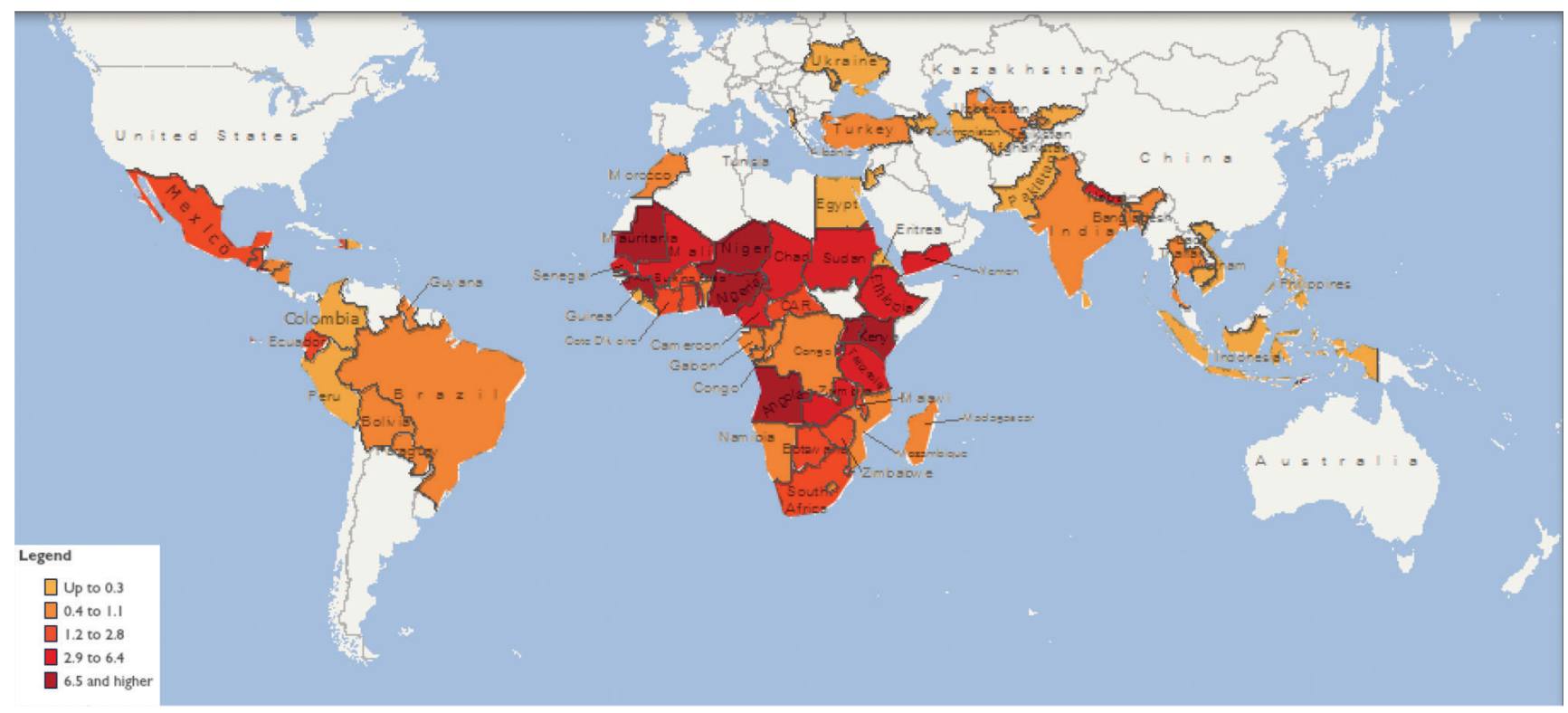

Source of data: STATcompiler.

to have given birth alone. Improvements in mothers' level of education were associated with reductions in the prevalence of women who gave birth alone across the 80 countries studied.

\section{DISCUSSION}

These analyses have shown that far too many women-roughly 2.2 million based on recent data from 59 countries-delivered alone, with no one present. This practice is taking place predominantly in parts of the world with the worst maternal and newborn health indicators such as West and Central Africa and parts of East Africa. Complications during pregnancy and childbirth are a leading cause of death and disability among women in developing countries. Women who deliver alone are particularly vulnerable, as they do not even have access to the marginal support any attendance at birth confers. While we are not calling for anything less than for all mothers and newborns to have access to quality skilled care, ensuring that no mother delivers alone is an urgent moral and human rights imperative.
Recent research publications examined the issue of Nigerian women who gave birth with NOP. $^{6-8}$ They found that the highest risk factors were poverty, rural residence, and rising maternal age. Our analysis confirms these findings both within Nigeria and across all countries studied. Nigeria, in particular, had severe wealth disparities in terms of women delivering alone $126 \%$ of the poorest women deliver alone compared with $2 \%$ of the wealthiest women). This finding suggests that the severity of inequity linked to delivering alone in Nigeria is exceptionally high in contrast to other countries included in this study. We also found a high proportion of urban women in Nigeria who gave birth alone $(6 \%)$ in addition to a high proportion in rural areas $(17 \%)$. This may be emblematic of the fact that Nigeria, as Matthews et al. have documented, is a country with large urban inequalities and a substantial urban rich advantage. ${ }^{14}$ In rural areas of Nigeria, the exceptionally large proportion of women who gave birth alone may be a direct result of a fewer number of facilities in rural areas. ${ }^{15}$ In terms of maternal age, there was a clear pattern across the 
TABLE 3. Percentage of Women Whose Most Recent Birth ${ }^{a}$ Occurred With No One Present, Stratified by Antenatal Care (ANC) Visits, Birth Order of the Index Child, and Maternal Educational Levels

\begin{tabular}{|c|c|c|c|c|c|c|c|c|c|c|c|}
\hline \multirow[b]{2}{*}{ Country \& Survey Year } & \multirow[b]{2}{*}{ Total } & \multicolumn{3}{|c|}{$\begin{array}{c}\text { No. of ANC Visits for Recent } \\
\text { Birth }\end{array}$} & \multicolumn{4}{|c|}{$\begin{array}{l}\text { Birth Order of the Index } \\
\text { Child }\end{array}$} & \multicolumn{3}{|c|}{$\begin{array}{l}\text { Mother's Highest } \\
\text { Educational Level }\end{array}$} \\
\hline & & None & $1-3$ & $\geq \mathbf{4}$ & 1 & $2-3$ & $4-5$ & $\geq 6$ & None & Primary & $\begin{array}{l}\text { Secondary } \\
\text { or higher }\end{array}$ \\
\hline \multicolumn{12}{|l|}{ sub-Saharan Africa } \\
\hline Angola 2006-07 & 8.4 & NA & NA & NA & NA & NA & NA & NA & 13.3 & 7.9 & 0.0 \\
\hline Benin 2011-12 & 1.1 & 4.2 & 2.0 & 0.2 & 0.9 & 0.9 & 1.4 & 1.5 & 1.5 & 0.4 & 0.1 \\
\hline Botswana 1988 & 1.4 & NA & NA & NA & 0.3 & 1.7 & 1.8 & 1.9 & 4.0 & 0.4 & 0.0 \\
\hline Burkina Faso 2010 & 1.4 & 4.3 & 1.6 & 0.5 & 0.0 & 1.4 & 1.7 & 1.8 & 1.6 & 0.3 & 0.1 \\
\hline Burundi 2010 & 3.6 & 16.7 & 4.0 & 2.5 & 0.8 & 2.3 & 5.6 & 6.5 & 4.6 & 2.9 & 0.3 \\
\hline Cameroon 2011 & 3.1 & 9.6 & 3.1 & 1.5 & 0.6 & 2.0 & 3.2 & 7.6 & 8.1 & 2.0 & 0.4 \\
\hline $\begin{array}{l}\text { Central African Republic } \\
\text { 1994-95 }\end{array}$ & 1.8 & 3.7 & 1.3 & 1.2 & 0.2 & 1.7 & 2.4 & 2.9 & 2.4 & 1.2 & 1.0 \\
\hline Chad 2004 & 4.0 & 5.1 & 2.8 & 2.7 & 0.9 & 3.7 & 4.1 & 6.3 & 3.8 & 5.5 & 1.4 \\
\hline Comoros & 0.9 & 5.6 & 0.5 & 0.3 & 0.2 & 0.8 & 1.1 & 1.6 & 1.6 & 0.6 & 0.1 \\
\hline Congo (Brazzaville) 2011-12 & 0.5 & 3.4 & 0.6 & 0.2 & 0.1 & 0.4 & 0.6 & 1.3 & 1.7 & 0.8 & 0.2 \\
\hline $\begin{array}{l}\text { Congo Democratic Republic } \\
2013-14\end{array}$ & 0.8 & 2.0 & 0.6 & 0.8 & 0.2 & 0.4 & 1.3 & 1.3 & 1.2 & 1.1 & 0.4 \\
\hline Côte d'Ivoire 2011-12 & 2.4 & 8.7 & 2.7 & 0.9 & 0.5 & 1.8 & 3.3 & 4.8 & 3.0 & 1.8 & 0.5 \\
\hline Eritrea 2002 & 0.3 & 0.5 & 0.1 & 0.2 & 0.0 & 0.2 & 0.0 & 0.8 & 0.3 & 0.3 & 0.0 \\
\hline Ethiopia 2011 & 3.8 & 4.5 & 2.6 & 3.4 & 2.1 & 3.5 & 3.1 & 6.0 & 4.2 & 3.3 & 1.3 \\
\hline Gabon 2012 & 0.4 & 2.4 & 0.3 & 0.3 & 0.3 & 0.2 & 0.6 & 0.6 & 0.2 & 0.7 & 0.3 \\
\hline Gambia 2013 & 1.9 & 23.9 & 2.7 & 1.4 & 0.6 & 1.6 & 1.6 & 4.1 & 2.1 & 1.5 & 1.9 \\
\hline Ghana 2008 & 2.7 & 8.6 & 4.4 & 2.1 & 0.4 & 0.9 & 5.8 & 6.5 & 4.3 & 2.8 & 1.5 \\
\hline Guinea 2012 & 7.1 & 20.5 & 5.6 & 4.9 & 2.7 & 4.9 & 9.5 & 12.1 & 8.7 & 2.4 & 1.1 \\
\hline Kenya 2008-09 & 6.5 & 17.2 & 6.7 & 4.5 & 0.5 & 3.7 & 9.4 & 16.2 & 8.0 & 7.6 & 3.0 \\
\hline Lesotho 2009 & 1.0 & 3.5 & 1.1 & 0.6 & 0.4 & 0.7 & 2.7 & 2.4 & 3.1 & 1.3 & 0.5 \\
\hline Liberia 2013 & 0.2 & 1.0 & 0.6 & 0.1 & 0.0 & 0.1 & 0.4 & 0.4 & 0.2 & 0.3 & 0.0 \\
\hline Madagascar 2008-09 & 0.8 & 3.6 & 0.6 & 0.3 & 0.0 & 0.6 & 0.6 & 2.1 & 1.0 & 0.9 & 0.2 \\
\hline Malawi 2010 & 2.7 & 15.1 & 2.7 & 2.3 & 0.6 & 1.6 & 3.2 & 6.4 & 4.2 & 2.7 & 1.2 \\
\hline Mali 2012-13 & 5.8 & 11.8 & 4.7 & 3.0 & 3.6 & 4.5 & 6.1 & 8.9 & 6.3 & 4.8 & 1.5 \\
\hline Mauritania 2000-01 & 6.9 & 11.0 & 5.6 & 3.0 & 4.4 & 7.2 & 6.3 & 9.1 & 9.2 & 3.3 & 1.5 \\
\hline Mozambique 2011 & 1.1 & 0.4 & 1.2 & 1.3 & 0.7 & 0.8 & 1.3 & 1.9 & 1.2 & 1.1 & 1.1 \\
\hline
\end{tabular}


Table 3 (continued).

\begin{tabular}{|c|c|c|c|c|c|c|c|c|c|c|c|}
\hline \multirow[b]{2}{*}{ Country \& Survey Year } & \multirow[b]{2}{*}{ Total } & \multicolumn{3}{|c|}{$\begin{array}{c}\text { No. of ANC Visits for Recent } \\
\text { Birth }\end{array}$} & \multicolumn{4}{|c|}{$\begin{array}{l}\text { Birth Order of the Index } \\
\text { Child }\end{array}$} & \multicolumn{3}{|c|}{$\begin{array}{l}\text { Mother's Highest } \\
\text { Educational Level }\end{array}$} \\
\hline & & None & $1-3$ & $\geq \mathbf{4}$ & 1 & $2-3$ & 4-5 & $\geq 6$ & None & Primary & $\begin{array}{l}\text { Secondary } \\
\text { or higher }\end{array}$ \\
\hline Namibia 2013 & 0.9 & 5.9 & 2.1 & 0.5 & 0.1 & 0.8 & 1.8 & 2.4 & 4.0 & 1.9 & 0.3 \\
\hline Niger 2012 & 14.5 & 15.0 & 15.0 & 13.7 & 6.4 & 11.2 & 16.7 & 19.1 & 15.7 & 10.1 & 3.6 \\
\hline Nigeria & 13.0 & 21.5 & 17.1 & 6.8 & 4.3 & 9.9 & 14.6 & 22.6 & 21.7 & 9.7 & 2.6 \\
\hline Rwanda 2013 & 7.3 & 36.4 & 8.7 & 3.7 & 1.0 & 6.2 & 10.1 & 15.3 & 11.7 & 6.7 & 2.9 \\
\hline Sao Tome and Principe 2008-09 & 0.0 & 0.0 & 0.0 & 0.0 & 0.0 & 0.0 & 0.0 & 0.0 & 0.0 & 0.0 & 0.0 \\
\hline Senegal 2012-13 & 5.1 & 23.6 & 5.8 & 2.7 & 1.4 & 3.2 & 7.5 & 9.5 & 6.3 & 3.5 & 0.8 \\
\hline Sierra Leone 2013 & 0.2 & 0.0 & 0.4 & 0.1 & 0.0 & 0.1 & 0.2 & 0.3 & 0.2 & 0.0 & 0.0 \\
\hline South Africa 1998 & 2.1 & 6.5 & 2.3 & 1.7 & 0.4 & 1.5 & 3.5 & 7.8 & 7.6 & 3.1 & 0.9 \\
\hline Sudan $1989-90$ & 4.3 & NA & NA & NA & 4.1 & 4.2 & 3.8 & 4.8 & 7.4 & 0.4 & 0.5 \\
\hline Swaziland 2006-07 & 4.4 & 15.2 & 4.6 & 3.8 & 0.9 & 3.1 & 8.3 & 12.3 & 10.6 & 6.1 & 2.4 \\
\hline Tanzania 2010 & 3.5 & 6.5 & 4.2 & 2.2 & 0.2 & 2.6 & 3.6 & 7.9 & 3.7 & 3.7 & 0.7 \\
\hline Togo 2013-14 & 3.1 & 13.5 & 3.4 & 1.5 & 0.5 & 2.7 & 2.6 & 8.4 & 5.0 & 2.4 & 0.9 \\
\hline Uganda 2011 & 6.8 & 14.1 & 8.6 & 4.3 & 1.2 & 3.3 & 7.4 & 13.7 & 12.5 & 7.2 & 2.2 \\
\hline Zambia & 3.1 & 7.0 & 3.5 & 2.6 & 0.1 & 1.1 & 3.0 & 9.2 & 8.0 & 3.5 & 0.9 \\
\hline Zimbabwe 2013-14 & 2.8 & 5.0 & 2.9 & 2.3 & 0.5 & 2.0 & 6.2 & 10.4 & 10.7 & 4.2 & 2.1 \\
\hline \multicolumn{12}{|c|}{ North Africa/West Asia and Eastern Europe } \\
\hline Albania 2008-09 & 0.1 & 4.1 & 0.0 & 0.0 & 0.2 & 0.0 & 0.0 & 0.0 & 6.1 & 0.0 & 0.0 \\
\hline Armenia 2010 & 0.0 & 0.0 & 0.0 & 0.0 & 0.0 & 0.0 & 0.0 & 0.0 & 0.0 & 0.0 & 0.0 \\
\hline Azerbaijan 2006 & 0.3 & 1.6 & 0.0 & 0.0 & 0.0 & 0.7 & 0.0 & 0.0 & 0.0 & 0.0 & 0.3 \\
\hline Egypt 2014 & 0.1 & 0.7 & 0.1 & 0.0 & 0.0 & 0.1 & 0.2 & 0.2 & 0.2 & 0.1 & 0.1 \\
\hline Jordan 2012 & 0.2 & 1.3 & 2.3 & 0.0 & 0.0 & 0.3 & 0.1 & 0.1 & 0.0 & 0.1 & 0.2 \\
\hline Moldova 2005 & 0.2 & 0.0 & 0.0 & 0.2 & 0.0 & 0.4 & 0.0 & 0.0 & 0.0 & 0.0 & 0.2 \\
\hline Morocco 2003-04 & 1.1 & 1.8 & 0.7 & 0.8 & 0.0 & 0.4 & 1.9 & 4.6 & 1.7 & 0.0 & 0.1 \\
\hline Turkey 1998 & 0.7 & 1.8 & 0.8 & 0.0 & 0.1 & 0.5 & 0.7 & 4.0 & 1.5 & 0.7 & 0.0 \\
\hline Ukraine 2007 & 0.0 & 0.0 & 0.0 & 0.0 & 0.0 & 0.0 & 0.0 & 0.0 & 0.0 & 0.0 & 0.0 \\
\hline Yemen 1997 & 4.4 & 5.1 & 3.1 & 3.5 & 1.7 & 3.1 & 4.3 & 6.5 & 4.8 & 2.9 & 3.1 \\
\hline \multicolumn{12}{|l|}{ Central Asia } \\
\hline Kyrgyz Republic 2012 & 0.1 & 0.0 & 0.0 & 0.2 & 0.4 & 0.0 & 0.0 & 0.0 & 0.0 & 0.0 & 0.0 \\
\hline Tajikistan 2012 & 0.1 & 0.3 & 0.3 & 0.0 & 0.1 & 0.1 & 0.4 & 0.0 & 2.5 & 0.0 & 0.1 \\
\hline Turkmenistan 2000 & 0.2 & 17.0 & 0.0 & 0.0 & 0.2 & 0.2 & 0.0 & 0.0 & 0.0 & 0.0 & 0.2 \\
\hline
\end{tabular}


Table 3 (continued).

\begin{tabular}{|c|c|c|c|c|c|c|c|c|c|c|c|}
\hline \multirow[b]{2}{*}{ Country \& Survey Year } & \multirow[b]{2}{*}{ Total } & \multicolumn{3}{|c|}{$\begin{array}{c}\text { No. of ANC Visits for Recent } \\
\text { Birth }\end{array}$} & \multicolumn{4}{|c|}{$\begin{array}{l}\text { Birth Order of the Index } \\
\text { Child }\end{array}$} & \multicolumn{3}{|c|}{$\begin{array}{l}\text { Mother's Highest } \\
\text { Educational Level }\end{array}$} \\
\hline & & None & $1-3$ & $\geq \mathbf{4}$ & 1 & $2-3$ & $4-5$ & $\geq 6$ & None & Primary & $\begin{array}{l}\text { Secondary } \\
\text { or higher }\end{array}$ \\
\hline Uzbekistan 1996 & 0.4 & 2.0 & 0.0 & 0.3 & 0.0 & 0.0 & 0.0 & 1.9 & 0.0 & 0.0 & 0.4 \\
\hline \multicolumn{12}{|l|}{ South and Southeast Asia } \\
\hline Bangladesh 2011 & 0.4 & 0.6 & 0.5 & 0.2 & 0.0 & 0.4 & 1.9 & 0.0 & 0.7 & 0.6 & 0.3 \\
\hline Cambodia 2010 & 0.0 & 0.0 & 0.0 & 0.0 & 0.0 & 0.0 & 0.0 & 0.0 & 0.0 & 0.0 & 0.0 \\
\hline India 2005-06 & 0.5 & 1.1 & 0.5 & 0.2 & 0.1 & 0.5 & 0.9 & 1.5 & 0.9 & 0.3 & 0.1 \\
\hline Indonesia 2012 & 0.2 & 2.4 & 1.3 & 0.1 & 0.2 & 0.1 & 0.9 & 1.4 & 1.3 & 0.5 & 0.1 \\
\hline Nepal 2011 & 2.9 & 9.5 & 2.4 & 1.3 & 0.6 & 2.0 & 6.5 & 12.0 & 4.5 & 2.7 & 1.0 \\
\hline Pakistan 2012-13 & 0.2 & 0.4 & 0.1 & 0.1 & 0.0 & 0.2 & 0.2 & 0.2 & 0.3 & 0.0 & 0.0 \\
\hline Philippines 2013 & 0.1 & 0.4 & 0.2 & 0.1 & 0.0 & 0.1 & 0.0 & 0.4 & 1.4 & 0.4 & 0.0 \\
\hline Sri Lanka 1987 & 0.2 & NA & NA & NA & 0.0 & 0.1 & 0.9 & 0.7 & 0.7 & 0.3 & 0.2 \\
\hline Thailand 1987 & 1.0 & NA & NA & NA & 0.2 & 1.0 & 1.8 & 4.2 & 0.3 & 1.0 & 1.2 \\
\hline Timor-Leste 2009-10 & 3.0 & 5.4 & 3.5 & 2.2 & 1.1 & 2.2 & 2.6 & 5.4 & 4.9 & 3.2 & 1.3 \\
\hline Vietnam 2002 & 0.1 & 0.3 & 0.1 & 0.0 & 0.0 & 0.0 & 0.6 & 2.0 & 1.1 & 0.0 & 0.0 \\
\hline \multicolumn{12}{|c|}{ Latin America and the Caribbean } \\
\hline Bolivia 2008 & 0.9 & 2.9 & 1.4 & 0.5 & 0.2 & 0.7 & 1.3 & 2.2 & 3.3 & 1.2 & 0.2 \\
\hline Brazil 1996 & 0.6 & 1.7 & 1.2 & 0.3 & 0.2 & 0.3 & 1.6 & 1.9 & 0.3 & 1.0 & 0.3 \\
\hline Colombia 2010 & 0.2 & 1.1 & 0.8 & 0.1 & 0.0 & 0.2 & 0.4 & 1.1 & 1.0 & 0.5 & 0.1 \\
\hline Dominican Republic 2013 & 0.1 & 3.2 & 0.0 & 0.1 & 0.0 & 0.1 & 0.4 & 0.5 & 1.0 & 0.0 & 0.1 \\
\hline Ecuador 1987 & 2.2 & NA & NA & NA & 0.8 & 1.6 & 2.5 & 4.9 & 9.5 & 2.0 & 0.2 \\
\hline El Salvador 1985 & 7.6 & NA & NA & NA & 2.9 & 5.6 & 9.8 & 16.1 & 17.4 & 4.8 & 0.0 \\
\hline Guatemala 1998-99 & 1.2 & 2.7 & 3.2 & 0.4 & 0.3 & 0.7 & 1.2 & 2.9 & 2.3 & 1.0 & 0.0 \\
\hline Guyana 2009 & 0.6 & 0.0 & 0.0 & 0.7 & 0.0 & 0.8 & 1.1 & 0.6 & 0.0 & 0.2 & 0.7 \\
\hline Haiti 2012 & 1.9 & 2.7 & 2.1 & 1.7 & 0.5 & 2.1 & 3.3 & 2.9 & 3.6 & 1.7 & 1.1 \\
\hline Honduras 2011-12 & 0.6 & 3.3 & 1.0 & 0.5 & 0.1 & 0.7 & 1.2 & 1.8 & 3.2 & 0.8 & 0.1 \\
\hline Mexico 1987 & 2.6 & NA & NA & NA & 0.6 & 0.8 & 3.8 & 7.3 & 8.6 & 2.2 & 0.3 \\
\hline Nicaragua 2001 & 1.1 & 3.0 & 1.5 & 0.6 & 0.0 & 0.4 & 1.6 & 4.3 & 3.5 & 0.6 & 0.2 \\
\hline Paraguay 1990 & 0.5 & 2.7 & 0.2 & 0.4 & 0.0 & 0.1 & 1.4 & 1.2 & 0.0 & 0.7 & 0.0 \\
\hline Peru 2012 & 0.3 & 2.1 & 0.0 & 0.3 & 0.0 & 0.2 & 0.9 & 1.7 & 0.5 & 1.0 & 0.1 \\
\hline Trinidad and Tobago 1987 & 0.1 & NA & NA & NA & 0.0 & 0.0 & 0.5 & 0.0 & 0.0 & 0.2 & 0.0 \\
\hline
\end{tabular}


countries included in our analysis that prevalence of giving birth alone increased with increasing maternal age. Given the constellation of extant risks for advanced maternal age, older mothers who deliver alone are particularly vulnerable to complications. ${ }^{16}$ However, in Nigeria and Niger, there was also a high proportion of young mothers who delivered alone; these young, often nulliparous, adolescent mothers who deliver alone are at significantly higher risk of developing obstetric fistula. ${ }^{17}$

Our analysis suggests that the drivers of delivery with NOP are of a structural nature, and not presumptively cultural. Across all 80 countries studies, the pattern was strikingly consistent, showing that women who gave birth alone were poor, had little education, and lived in rural areas. As the global community works to reduce inequalities in socioeconomic and health indicators, it will also likely have impact on eradicating delivery with NOP.

At the same time, evidence from Sokoto State, in northern Nigeria, suggests that the prevalence of delivery with NOP can be eliminated almost entirely through targeted actions by key stakeholders, along with education and advocacy, even in a population where poverty is pervasive, resources are scarce, and women are poorly educated. In 2008, the DHS reported that the prevalence of delivery with NOP in Sokoto State was 25\%; by 2013, the prevalence had dropped to less than $1 \%$. $^{18,19}$

Sokoto State is situated in the northwest corner of Nigeria, with an estimated population of just over 4.6 million in 2013, 80\% of whom live in poverty. ${ }^{20,21}$ Data show that use of maternal health services in health facility settings is very low and has not improved in recent years; in both 2008 and 2013, 95\% of married women in Sokoto State reported having delivered their most recent child at home. ${ }^{18,19}$ Furthermore, more than $80 \%$ of women in the state in 2013 reported that they had not accessed any antenatal care during their most recent pregnancy. ${ }^{18,19}$ The low uptake of maternal health services may be a direct result of few services available. There have been investments in increasing access to and the availability of health services in Sokoto State, resulting in a $26 \%$ increase in the number of government-run health facilities between 2009 and 2015, from 600 facilities to 756 facilities. $^{22,23}$ Although efforts to increase the number of facilities have yielded results, the majority of women in Sokoto State, as noted above, still give birth at home.

The decline in delivery with NOP in Sokoto State coincided with multilevel discussions between government and civil society beginning in 2012 after the problem was first reported by JSI Research and Training Institute, Inc. (JSI) researchers. ${ }^{7}$ JSI researchers, working in Sokoto State with the Targeted State High Impact Project (TSHIP) funded by the United States Agency for International Development (USAID), shared their findings with government officials and civil society leaders. Whereas government officials in Sokoto State were surprised by the magnitude of the problem, community leaders were not. All parties agreed the status quo was not acceptable.

In addition to ongoing efforts to improve access to and use of quality maternal and newborn health services across Sokoto State, JSI/TSHIP began working with state-level leaders of Jama'atu Nasril Islam (JNI), Nigeria's largest, most-networked, Muslim nonprofit aid group, to address the issue of women delivering alone. JNI leadership took charge of sounding an alarm and raising awareness among government and civil society leaders in Sokoto State. JNI also issued a call to eliminate the practice of delivery with NOP. Throughout all 244 wards in Sokoto State, JNI mobilized its local leaders and briefed them on the dangers associated with giving birth with NOP. Additionally, JNI called for local leaders to publicly discourage giving birth alone in homes. In 2012, JNI leaders trained Muslim clerics throughout the state to use appropriate verses from the Koran and hadith (collections of sayings or traditions of the Prophet Muhammad) to highlight the dangers of giving birth with NOP in relation to maternal and newborn mortality. Muslim clerics, with support from JNI, started to preach in favor of delivery with skilled assistance during Friday congregational prayers, wedding fatihas (religious ceremonies), and naming ceremonies. These efforts were successful in educating communities in Sokoto State on the dangers associated with giving birth alone, and ultimately changing the societal norms that had, in the past, condoned and facilitated the practice of delivering with NOP.

As a complement to these efforts, JSI/TSHIP also worked with the state government officials and communities to launch a 2,440-strong female community-based health volunteer (CBHV) team in 2012. These 2,440 CBHVs, representing 10 CBHVs per ward, were trained to counsel mothers on delivery with skilled attendance; the CBHVs made a total of 389,000 documented household visits in 2013 alone. $^{23,24}$

The case of Sokoto State suggests that a process of community education and awareness has the potential to create ideation around norms in the short to medium term and can realistically

\section{Programmatic experience in northern Nigeria suggests that the practice of giving birth alone can be reduced markedly through community education and advocacy.}


accelerate the replacement of NOP-type deliveries with some type of attendance. This encouraging development is worth the attention of policy and civil society members across countries with relatively higher prevalence of deliveries with NOP. In itself, it is a call to action for leaders to act now alongside the broader implementation of SDG-related initiatives. The eradication of the practice of giving birth with NOP is only one step in ensuring that no mother or newborn dies of a preventable death. Ultimately, until every woman has safe, affordable, acceptable, and available maternal health services, there will remain barriers to achieving SDG targets 3.1 and 3.2.

\section{Study Limitations}

Several limitations to our analysis should be noted. First, the DHS methodology collects information on women giving birth alone only through self-report.

Second, as the DHS is conducted in many countries, with multiple language groups, it is possible that women may not have understood the question correctly and thus that they incorrectly reported that their most recent birth occurred with "no one" present, despite efforts undertaken by the DHS to mitigate complications that may arise due to translation. The protocol for the standard DHS questionnaire not only asked women directly about who assisted with their most recent delivery but also probed those respondents who said "no one" assisted to determine whether any adults were present at the time of delivery. ${ }^{25}$

Another issue that must be noted, particularly in the Sokoto State context where the practice of giving birth with NOP has been so publicly and widely discouraged, is that DHS respondents may be reluctant to share that they have delivered alone. If women, due to social pressure and/or stigma associated with giving birth alone, are unwilling to report giving birth alone, it would be impossible to detect that, given the DHS methodology. Research on whether or not covert delivery with NOP occurs would be best informed through other study designs.

In Table 2 and Table 3, we were unable to include the number of women who gave birth. Unfortunately, the STATcompiler database neither provided specific sample sizes nor numerators and denominators for the percentages presented.

Also, many of the countries have not had a recent DHS survey, precluding determination of current global burden of delivering with NOP.

Furthermore, in our analyses of the burden of women who gave birth alone, there are some disagreements between the age parameters from the US Census Bureau (population of women aged 15-49) and the general fertility rate, as calculated by the DHS, which includes only women between the age of 15-44. According to the DHS, "The General Fertility Rate (GFR) is for the three years preceding the survey expressed per 1,000 women age 15-44. Note however that births to all women 15-49 are included in the numerator. In practice, there are very few births to women age 45-49 so the difference compared to restricting to births to women age 15-44 would be very small." ${ }^{26}$

Finally, data available via STATcompiler could only be analyzed by using broad categories. Further research should use country-specific data to further explore the interactions between these predictive variables. Despite these data limitations, this analysis has shown that too many women are giving birth alone, and that grassroots advocacy and programmatic efforts are able to reduce the phenomena considerably, including in contexts where other socioeconomic determinants of health remain unchanged.

\section{CONCLUSION}

Giving birth alone is a problem of important magnitude in many low- and middle-income countries, particularly in those countries with the worst maternal and newborn health indicators such as in West and Central Africa and parts of East Africa. Community education and awareness has the potential to change cultural norms in the short and medium term, accelerating the replacement of deliveries with no one present with some type of attendance. Ensuring that no mother delivers alone is an urgent moral and human rights imperative to prevent avoidable maternal and newborn deaths.

Acknowledgments: This manuscript was funded by the United States Agency for International Development (USAID) Mission for Nigeria under the Targeted States High Impact Project (TSHIP), Cooperative Agreement No. 620-A-00-09-00014-00 and JSI Research \& Training Institute, Inc.

Competing Interests: None declared.

\section{REFERENCES}

1. Sustainable Development Knowledge Platform [Internet]. New York: United Nations, Division for Sustainable Development; c2014-2016 [cited 2015 Oct 8]. Transforming our world: the 2030 Agenda for Sustainable Development; [about 20 screens]. Available from: https://sustainabledevelopment.un.org/ post2015/transformingourworld

2. Sustainable Development Knowledge Platform [Internet]. New York: United Nations, Division for Sustainable Development; c2014-2016 [cited 2015 Oct 8]. Sustainable development goals; [about 5 screens]. Available from: hitps:// sustainabledevelopment.un.org/?menu=1300 
3. Campbell OMR, Graham WJ; Lancet Maternal Survival Series steering group. Strategies for reducing maternal mortality: getting on with what works. Lancet. 2006;368(9543):1284-1299. CrossRef. Medline

4. Tunçalp Ö, Were WM, MacLennan C, Oladapo OT, Gülmezoglu AM, Daelmans B, et al.. Quality of care for pregnant women and newborns-the WHO vision. BJOG. 2015;122(8):1045-1049. CrossRef. Medline

5. Austin A, Langer A, Salam RA, Lassi ZS, Das JK, Bhutta ZA. Approaches to improve the quality of maternal and newborn health care: an overview of the evidence. Reprod Health. 2014;11 Suppl (2):S1. CrossRef. Medline

6. Fapohunda B, Orobaton N. Factors influencing the selection of delivery with no one present in Northern Nigeria: implications for policy and programs. Int J Womens Health. 2014;6:171-183. CrossRef. Medline

7. Fapohunda BM, Orobaton NG. When women deliver with no one present in Nigeria: who, what, where and so what? PLoS One. 2013;8(7):e69569. CrossRef. Medline

8. Austin A, Fapohunda B, Langer A, Orobaton N. Trends in delivery with no one present in Nigeria between 2003 and 2013. Int J Womens Health. 2015;7:345-356. CrossRef. Medline

9. Corsi DJ, Neuman M, Finlay JE, Subramanian S. Demographic and health surveys: a profile. Int J Epidemiol. 2012;41(6):16021613. CrossRef. Medline

10. Prata N, Sreenivas A, Vahidnia F, Potts M. Saving maternal lives in resource-poor settings: facing reality. Health Policy. 2009; 89(2):131-148. CrossRef. Medline

11. Singh $K$, Brodish $P$, Suchindran $C$. A regional multilevel analysis: can skilled birth attendants uniformly decrease neonatal mortality? Matern Child Health J. 2014;18(1):242-249. CrossRef. Medline

12. STATcompiler [Internet]. Calverton (MD): DHS Program, ICF International; 1985- [cited 2016 Feb 17]. Available from: http:// www.statcompiler.com/

13. United States Census Bureau International Data Base [Internet]. Washington (DC): The Bureau; c2015 [updated 2015 Jul 9; cited 2015 Oct 13]. Available from: https://www.census.gov/ population/international/data/idb/informationGateway.php

14. Matthews Z, Channon A, Neal S, Osrin D, Madise N, Stones W. Examining the "urban advantage" in maternal health care in developing countries. PLoS Med. 2010;7(9):e1000327. CrossRef. Medline

15. Ademiluyi I, Aluko-Arowolo S. Infrastructural distribution of healthcare services in Nigeria: an overview. J Geogr Reg Plann. 2009;2(5):104-110. CrossRef.

16. Jolly M, Sebire N, Harris J, Robinson S, Regan L. The risks associated with pregnancy in women aged 35 years or older. Hum Reprod. 2000;15(1 1):2433-2437. CrossRef. Medline
17. Wall LL. Obstetric vesicovaginal fistula as an international publichealth problem. Lancet. 2006;368(9542):1201-1209. CrossRef. Medline

18. National Population Commission (NPC) [Nigeria] and ICF International. Nigeria Demographic and Health Survey 2008. Abuja (Nigeria): The Commission; 2008. Available from: http:// www.dhsprogram.com/pubs/pdf/FR222/FR222.pdf

19. National Population Commission (NPC) [Nigeria] and ICF International. 20. Nigeria Demographic and Health Survey 2013. Abuja (Nigeria): The Commission; 2014. Available from: http://dhsprogram.com/pubs/pdf/FR293/FR293.pdf

20. National Bureau of Statistics [Nigeria]. Nigeria poverty profile 2010. Abuja (Nigeria): The Bureau; 2012 Jan. Available from: http://mww. nigerianstat.gov.ng/pdfuploads/Nigeria Poverty Profile 2010.pdf

21. United Nations Fund for Population Activities (UNFPA), Nigeria [Internet]. Abuja (Nigeria): UNFPA; c2009-2016 [cited 2015 May 5]. UNFPA supports traditional and religious leaders to mobilize for increased utilization of maternal health services in Sokoto State; [about 3 screens]. Available from: http://nigeria.unfpa. org/sokoto.html. URL was accessed during writing of this article but was no longer available by the time of publication.

22. Targeted States High Impact Project (TSHIP). Targeted States High Impact Project (TSHIP) Sokoto State baseline report. [Boston: JSI Research \& Training Institute, Inc.; 2009]. Available from: http:// uww.tshipnigeria.org/index.php/publications/finish/ 3-publications/2-bauchi-and-sokoto-states-health-facility-rapidassessment-baseline-survey-report. URL was accessed during writing of this article but was no longer available by the time of publication.

23. Targeted States High Impact Project (TSHIP). Targeted States High Impact Project (TSHIP) final report, December 2015. [Boston: JSI Research \& Training Institute, Inc.; 2015]. Available from: http://www.jsi.com/JSllnternet/Resources/publication/display. $\mathrm{cfm}$ ? $\mathrm{t} \times \mathrm{Heo}$ Area $=$ INTL\&id $=16332$ \& thisSection $=$ Resources . URL was accessed during writing of this article but was no longer available by the time of publication.

24. Orobaton N, Abegunde D, Shoretire K, Abdulazeez J, Fapohunda B, Lamiri $G$, et al. A report of at-scale distribution of chlorhexidine digluconate $7.1 \%$ gel for newborn cord care to 36,404 newborns in Sokoto State, Nigeria: initial lessons learned. PLoS One. 2015;10(7): e0134040. CrossRef. Medline

25. The DHS Program [Internet]. Calverton (MD): DHS Program, ICF International; c2015-2016 [cited 2015 Aug 28]. DHS model questionnaires; [about 4 screens]. Available from: http:// dhsprogram.com/What-We-Do/Survey-Types/DHSQuestionnaires.cfm

26. Trevor-DHS. Re: Age range for the GFR in STATcompiler. In: The DHS Program User Forum [Internet]. Calverton (MD): DHS Program, ICF International; 2015 Oct 26. [cited 2015 Oct 27]; [about 1 screen]. Available from: http://userforum. dhsprogram.com/index.php?S $=74512 \mathrm{~d} 5908 \mathrm{c} 61 \mathrm{~d} 29$ fee2a5e5737d3c55

\section{Peer Reviewed}

Received: 2015 Aug 28; Accepted: 2016 Jan 23; First Published Online: 2016 Mar 9

Cite this article as: Orobaton N, Austin A, Fapohunda B, Abegunde D, Omo K. Mapping the prevalence and sociodemographic characteristics of women who deliver alone: evidence from demographic and health surveys from 80 countries. Glob Health Sci Pract. 2016; 4(1):99-113. http://dx.doi.org/10.9745/GHSP-D-15-00261.

(c) Orobaton et al. This is an open-access article distributed under the terms of the Creative Commons Attribution License, which permits unrestricted use, distribution, and reproduction in any medium, provided the original author and source are properly cited. To view a copy of the license, visit http://creativecommons.org/licenses/by/3.0/. When linking to this article, please use the following permanent link: http://dx.doi.org/10.9745/GHSP-D-15-00261. 